\title{
The Social Universe of the English Bible: Scrip- ture, Society, and Culture in Early Modern Eng- land, by Naomi Tadmor
}

Cambridge: Cambridge University Press, 2010 | xvi + 208 pages | ISBN: 978-0-52 I-7697 I-6 (hardback) £55.00

So shall thy barnes be filled with plenty, and thy presses shall burst out with new

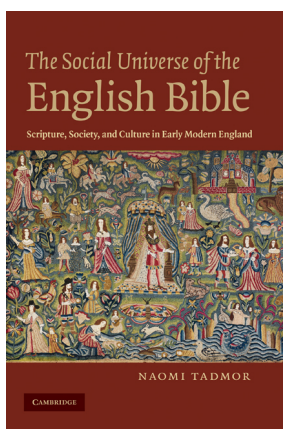
wine.

Proverbs 3:10

The years around 20I I commemorating the 40oth anniversary of the King James Bible (KJB) certainly have been full of plenty. The presses have been bursting with new studies exploring the significance and impact of the "authorized" version. One might imagine the reader to be sated: "a glutton and a drunkard" (Deut 2 I:20). Yet—and here we leave the image for now-Naomi Tadmor's The Social Universe of the English Bible: Scripture, Society, and Culture in Early Modern England is new wine in a new bottle (Mark 2:22); it sparkles.

Tadmor explores the role of the English Bible in the formation of a certain kind of nationhood. In a series of insightful close readings of words and passages she reveals how the process of translation through several versions shaped an "anglicised" consciousness across a period much occupied with emphasising its own generation. In particular, she focuses on the relationship between English versions of the Bible and "the propirties of the hebrue tonge" (William Tyndale's words). Through acute philological analyses of English translations of the Hebrew Bible, Tadmor demonstrates how a contemporary "living idiom" (I3) was anciently begot and future generating: "the semantic shifts and transpositions, which took place in the processes of translation, affected not just individual words but the construction of a social universe" (20).

Tadmor structures her persuasive argument around four main themes, each given a chapter, in which she argues that shifts in meaning which took place in translation "were textually telling and historically significant" (I7). The first section focuses on neighbourly relationships. In it the author argues that although ideas of early modern fellowship were "anchored in the language of the Holy Scriptures" translators rendered the Hebrew re'a (friend, companion, fellow man, every man) as "neighbour." The term was then employed as a "directive for social action" (26), with political consequences. 
The second chapter on women and wives develops ideas from Tadmor's earlier published papers that explored the idioms of marriage exposed by early modern Bible translations. ${ }^{1}$ Tadmor argues that these "naturalised" and "habituated" monogamous modes (53). She provides a detailed trail of the cumulative effect of "Englishing" on social regulation which, in parallel to other transformations, "served to propagate a biblically inspired doctrine of marriage" (67). Gendered formulations posited as intrinsic are, as we might anticipate, politically inspired. Essentialism is after all a social construct. If this is not exactly news, the level of detail that Tadmor provides persuades us of the extent to which linguistic tools were used to build the master's house, to give foundations to a system of patriarchal "fatherly superiority" (I 59).

In chapter three, Tadmor discusses the way in which early modern translation also normalised "master-servant" relationships and embedded a language of slavery and bondage found in biblical laws, proverbs and aphorisms. She claims that Latin translations had reflected notions of "un-free labour" (94). By the Middle Ages ideas of serfdom had changed; there was bondage of blood as well as tenancy. Tadmor notes that the Wyclifite rendition mistranslates servus for "servant." Tyndale's subsequent retention of the word had a major influence: "his Anglicised language of 'service' remained current in years to come (indeed, it is estimated that around 80 per cent of the text of the Authorised Version is still based on Tyndale)" (97). Designations of service relationships and claims that follow them were thus "successfully anchored in the Divine Word of the biblical text" (I07).

Tadmor's final chapter deals with English biblical polity, the order of church and state. English Bibles, she contends, "left no room for doubt that the ancient polities of the Hebrew Old Testament were headed by 'princes' and that princely rule therefore was of an unquestionably ancient and holy provenance" (I 2 I). The consequences of such claims were played out through the formation of monarchical government and (for one ruler at least) the fatal machinations of Charles I and his contemporaries.

There were other causes and consequences to the struggle for biblical supremacy that might have featured here more strongly. These relate to internecine conflicts within the reforming churches and between other religions of the book. Tadmor mentions Luther's I 523 translation of the Pentateuch from the Hebrew original, inspired by his claim for justification by scripture $(2-3)$. Other historians have noted that Luther's mission related to a

${ }^{1}$ E.g., Naomi Tadmor, "Women and Wives: The Language of Marriage in Early Modern English Biblical Translations", History Workshop Journal 62, no. I (2006): I-27. 
perceived threat of Jewish scriptural scholarship, not only to interpretation of the Word but also to Christian social structures. For instance, Raphael Hallett (no known relation to this reviewer) has argued in his essay " "Vile Interpretations" that Luther conceived "linguistic threat spreads through from the historical tradition of Jewish exegesis," a threat not just to text but to body with "Christian persona" under "social and theological siege." locates Luther's attempts, like those of Tyndale, in trying to release the text from "the shackles of Rome" (3). Hallett argues that, because of the rigour of their reference to the Hebrew scriptures, "For Luther, meticulous scriptural engagement with the intractable Jews is more urgent and necessary than with the deluded Catholics" (92). There were, then, several reasons for pressing translation back to the original language.

It is here that we might wish for a more extended study, one beyond the remit Tadmor quite reasonably sets for her book. Among other things, she has raised for us intriguing issues about the role of mistranslation in what might be termed propaganda, and the ways in which claimants of biblical authority use their status to perpetuate oppression, in terms of gender, labour and other means through the early modern period and beyond. Having read Tadmor's book we might also wish to consider further implications of ways in which etymologists have elided as well as elicited meaning. It would be interesting to explore the extent of knowledge of Hebrew in early modern England, to understand how far readers would be aware, resistant, or complicit, in perpetuating error.

We might wish to examine the literary and social repercussions of linguistic twisting, some of it innocent through negligence, and some of it less so. The claims about kingship and authority in Shakespeare, for example, have themselves perpetuated mis-readings, in turn exacerbated by critical claims about early modern hierarchies. Between I 564 and I6I6 some 2 I I editions of the Bible were produced and around 422,000 copies sold (9). While Tadmor refers several times to Shakespeare (his use of "captain" in Henry $V$, and to Brutus "made one" in matrimonial-speak with conspirators in Julius Caesar, 5.5.72), further studies might expose the ways in which literature has played its part in accreting tyrannies of words.

${ }^{2}$ Raphael Hallett, “'Vile Interpretations' and 'Devilish Supplements': Jewish Exegesis and Linguistic Siege in Martin Luther's On the Jews and Their Lies (I 543)", in The Religions of the Book: Christian Perceptions, I400-I60o, ed. Matthew Dimmock and Andrew Hadfield (New York: Palgrave Macmillan, 2008). 
More significant still, perhaps, Tadmor's work has implications beyond the early modern period. We might hope for further exploration of the role of language and wilful misreading by those seeking to justify more recent atrocities.

This is a fine and fruitful investigation; one ripe for development in keeping with all good studies. It provides a persuasively detailed account of how a text in transmission and transition translated its own values on to and away from ancient sources in order to foment a fresh "social universe." If "newe wine take away the heart" (Hos 4:I I) this book restores it.

Nicky Hallett

University of Sheffeeld 